\title{
PENJADWALAN 20 JOB 8 MESIN DENGAN METODE GENETIC ALGORITHM (GA)
}

\author{
Didit Damur Rochman ${ }^{1}$, Rendiyatna Ferdian ${ }^{2}$ \\ Program Studi Teknik Industri, Fakultas Teknik, Universitas Widyatama \\ Jl Cikutra No 204A Bandung 40125 \\ Telp. (022) 7275855 ext. 131, Faks (022) 7278860 \\ Email: ${ }^{1}$ diditdr@widyatama.ac.id, ${ }^{2}$ rendiyatna.ferdian@widyatama.ac.id
}

\begin{abstract}
ABSTRAK
Penelitian ini merupakan perluasan dari penelitian sebelumnya yang dilakukan oleh Iskandar (2013) dengan judul "IMPLEMENTASI PENJADWALAN MESIN JOB SHOP DENGAN METODE HEURISTIC DISPATCHING RULES DI CV BOEING TEKNIK MANDIRI". Pada penelitian tersebut dilakukan penjadwalan mesin job shop dengan menggunakan metode Heuristic Dispatching Rules. Tujuan dari penelitian ini adalah untuk melakukan penjadwalan mesin job shop dengan menggunakan metode Genetic Algorithm dan membandingkan hasil yang didapat dengan hasil penjadwalan yang dilakukan Iskandar (2013) dengan metode Heuristic Dispatching Rules. Setelah dilakukan proses pengolahan data dengan menggunakan metode Genetic Algorithm selama 27 menit 33 detik, didapatkan hasil penjadwalan untuk kriteria Cmax (Completion Time Maximum) sebesar 2391,017 menit, kriteria Fmax (Flow Time Maximum) sebesar 2391,017 menit, kriteria Lmax (Lateness Maximum) sebesar -151,05 menit dan kriteria Tmax (Tardiness Maximum) sebesar 0 menit. Dibandingkan dengan hasil penjadwalan awal yang dilakukan oleh CV Boeing Teknik Mandiri, penjadwalan dengan menggunakan metode Genetic Algorithm dapat menghasilkan efisiensi sebesar 5,25\% dalam kriteria Cmax serta Fmax. Untuk kriteria Lmax metode Genetic Algorithm menghasilkan efisiensi sebesar 106,2\%.
\end{abstract}

Kata Kunci: Penjadwalan mesin, Job Shop, Metode Heuristic Dispatching Rules, Genetic Algorithm.

\section{PENDAHULUAN}

\section{A. Latar Belakang}

Penelitian ini merupakan pengembangan hasil penelitian sebelumnya yang dilakukan oleh Cepi Dea Iskandar pada tahun 2013 dengan judul "IMPLEMENTASI PENJADWALAN MESIN JOB SHOP DENGAN METODE HEURISTIC DISPATCHING RULES DI CV BOEING TEKNIK MANDIRI”. Pada penelitian tersebut dilakukan proses penjadwalan mesin pada CV Boeing Teknik Mandiri dengan menggunakan metode Heuristic Dispatching Rules. Penelitian yang dilakukan oleh Iskandar (2013) untuk penjadwalan mesin hanya dilakukan dengan menggunakan satu metode yaitu Heuristic Dispatching Rule tanpa ada pembanding metode lainnya. Proses penjadwalan mesin yang dilakukan Iskandar (2013) dengan metode Heuristic Dispatching Rules menghasilkan kesimpulan bahwa LWKR (Least Work Remaining) merupakan prioritas terbaik untuk diterapkan pada CV Boeing Teknik Mandiri. Hal tersebut ditunjukan dengan kriteria waktu Cmax (Completion Time) sebesar 2442,27 menit, Lmax (Lateness) 2442,15 menit, Fmax (Flow Time) sebesar 2442,27 menit dan Tmax (Tardiness) sebesar 2442,15 menit. Dari hasil tersebut didapatkan bahwa penjadwalan mesin CV Boeing Teknik Mandiri dengan metode Heuristic Dispatching Rules dapat menghemat waktu produksi sebesar 3\%.

Hasil pengamatan yang dilakukan Iskandar (2013), CV Boeing Teknik Mandiri memiliki keterbatasan dalam hal kapasitas produksi mesin. Keterbatasan kapasitas mesin tersebut seringkali menyebabkan perusahaan sulit dalam melakukan proses produksi. Jika penyerahan produk pada konsumen mengalami keterlambatan, maka perusahaan akan terkena penalti dari konsumen atau konsumen tidak akan melakukan pemesanan kepada perusahaan pada periode selanjutnya. Jumlah produk yang mengalami keterlambatan 
pengiriman kepada konsumen, berdasarkan wawancara dengan pemilik perusahaan adalah sebesar 2-5\% dari seluruh pemesanan dengan lama keterlambatan antara 2-6 hari. Hal ini dapat membawa pada permasalahan finansial yang cukup serius jika tidak ditangani dan diselesaikan berdasarkan prinsip pengelolaan perusahaan yang baik. Disamping itu, kondisi di perusahaan saat ini, tidak menggunakan perencanaan yang tertulis, sehingga menyulitkan dalam tracking status pengerjaan produk. Hal ini terjadi karena pada perusahaan ini, semua proses manajemen dipegang langsung oleh pemilik (Iskandar, 2013).

\section{B. Tujuan Penelitian}

Berdasarkan latar belakang yang ada, maka tujuan dari dilakukannya penelitian mengenai penjadwalan mesin ini adalah:

- Melakukan penjadwalan mesin pada CV Boeing Teknik Mandiri dengan menggunakan metode Genetic Algorithm (GA) untuk meminimumkan kriteria completion time.

- Membandingkan hasil efisiensi penjadwalan mesin pada CV Boeing Teknik Mandiri dengan metode Genetic Algorithm dengan penelitian terdahulu dengan menggunakan pendekatan Heuristic Dispatching Rules berdasarkan kriteria completion time.

\section{Batasan Masalah}

Untuk menghindari penelitian yang terlalu luas dan dapat menghasilkan penelitian yang lebih mengarah pada fokus permasalahan, maka penulis mengambil beberapa batasan masalah dan asumsi yang digunakan diantaranya:

- Metode yang digunakan pada penelitian untuk kasus penjadwalan ini adalah metode Genetic Algorithm (GA).

- Program yang digunakan untuk penjadwalan mesin dengan metode Genetic Algorithm adalah Palisade Decision Tools (Evolver 6.1) versi trial. Versi trial program tersebut memiliki fungsi yang sama dengan versi full, hanya memiliki kekurangan batas waktu penggunaan yaitu selama 15 hari.

- Waktu transfer antar proses dianggap tidak ada.

- Ketersediaan bahan baku selalu ada.

\section{LANDASAN TEORI}

\section{A. Penjadwalan}

Penjadwalan dalam proses produksi merupakan sesuatu yang cukup penting, dalam proses penjadwalan dapat menentukan waktu yang dibutuhkan untuk proses produksi serta memprediksi jumlah produksi yang akan dihasilkan perusahaan dalam periode tertentu. Tujuan dari penjadwalan adalah untuk mengoptimalkan penggunaan sumber daya yang ada sehingga tujuan produksi secara keseluruhan dapat terpenuhi (Narasimhan, 1995).

\section{B. Genetic Algorithm}

Genetic Algorithm (GA) atau Algoritma Genetika merupakan cabang dari algoritma evolusi yang digunakan untuk memecahkan masalah optimasi. Algoritma ini didasarkan pada proses genetik yang terjadi pada makhluk hidup, dimana perkembangan generasi pada suatu populasi yang alami secara lama kelamaan akan mengikuti seleksi alam yaitu dimana yang kuat yang akan bertahan. Dengan mengikuti teori evolusi tersebut maka algoritma genetik ini dapat digunakan untuk memecahkan masalah yang terjadi pada sehari-hari.

Teori ini pertama kali ditemukan oleh John Holland, dalam algoritma ini bekerja dalam sebuah populasi yang terdiri dari individu-individu yang masing-masing individu merepresentasikan solusi yang ada. Dalam kaitan ini individu dilambangkan 
sebagai nilai fitness yang akan digunakan untuk menetukan solusi terbaik yang ada. Dalam prosesnya masing-masing individu tersebut akan melakukan reproduksi dengan cara perkawinan silang dengan individu lainnya untuk menghasilkan keturunan baru yang lebih baik. Dengan cara tersebut maka individu baru akan terus bermunculan, sedangkan untuk individu yang lemah akan mati sendiri. Semakin banyak proses perkawinan silang dilakukan, maka akan semakin banyak kemungkinan solusi yang akan diperoleh (Entin, 2010).

\section{METODOLOGI PENELITIAN}

Tahapan pengolahan data dengan menggunakan metode Genetic Algorithm dilakukan dengan melalui beberapa tahapan, diantaranya adalah sebagai berikut:

- Tahap 1: Menentukan tujuan yang akan digunakan dalam algoritma genetika yaitu minimasi completion time.

- Tahap 2: Melakukan komputasi dengan metode Genetic Algorithm, adapun langkahlangkah dalam komputasi dengan menggunakan metode Genetic Algorithm pada penelitian ini dapat dilihat pada gambar 1 berikut:

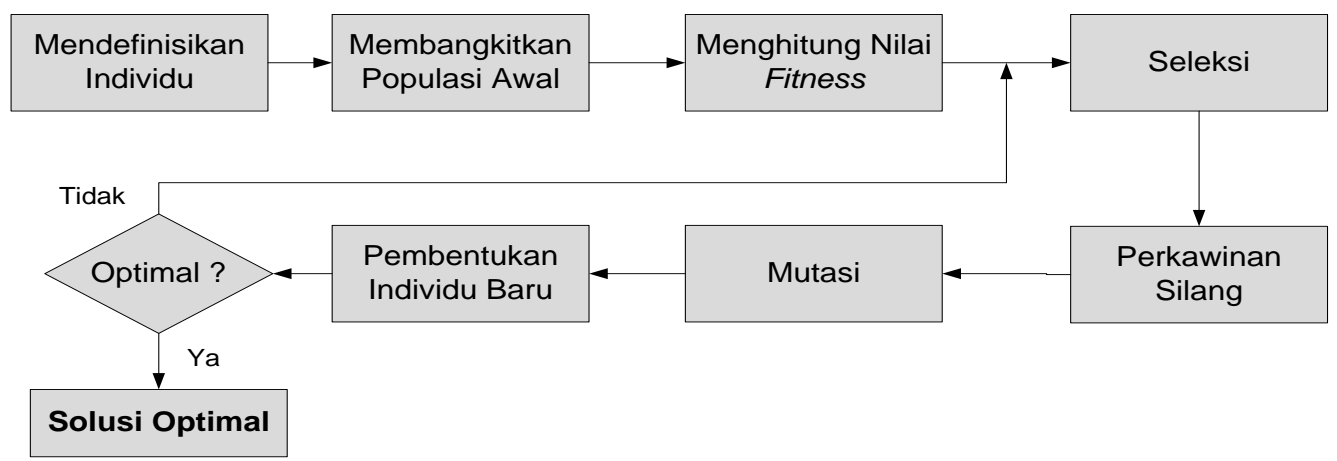

Gambar 1 Langkah-Langkah Proses Genetic Algorithm

\section{a. Mendefinisikan Individu}

Langkah pertama dalam metode Genetic Algorithm ini adalah dengan mendefinisikan individu. Individu dalam Genetic Algorithm merupakan solusi dari permasalahan yang akan diteliti. Dalam kasus penjadwalan mesin ini individu merupakan urutan proses dari mesin produksi.

Individu dalam kasus penjadwalan direpresentasikan dalam kromosom bilangan bulat. Dalam aturan ini jadwal diubah menjadi suatu rangkaian dari suatu operasi. Sebuah kromosom terdiri dari $n$ job dan $m$ mesin akan memiliki ukuran kromosom $m \times n$.

b. Membangkitkan Populasi Awal

Langkah selanjutnya dalam metode Genetic Algorithm adalah dengan membangkitkan populasi awal. Pembentukan populasi awal merupakan proses dalam Genetic Algorithm dimana sejumlah populasi akan dibangkitkan secara acak melalui prosedur tertentu. Dalam kasus penjadwalan mesin ini populasi yang dibentuk akan digunakan sebagai induk untuk mencari solusi yang baik. Dalam penelitian ini pembangkitan populasi awal dilakukan dengan cara random generator, dimana sejumlah nilai akan dibangkitkan dengan menggunakan bilangan random.

Langkah-langkah yang dilakukan dalam prsoses pembangkitan populasi awal adalah sebagai berikut:

- Membuat bilangan random sebanyak jumlah populasi yang diinginkan. 
- Jumlah panjang gen dalam suatu individu dalam kasus $m$ job dan $n$ mesin adalah $m$ $x n$.

- $\quad$ Hitung nilai fitness masing-masing individu dalam populasi.

\section{c. Menghitung Nilai Fitness}

Menghitung nilai fitness merupakan tahapan ketiga dalam metode Genetic Algorithm. Pada tahapan ini masing-masing individu akan dihitung nilai fitness untuk dijadikan sebagai ukuran baik tidaknya suatu solusi. Salah satu tujuan dari penjadwalan mesin adalah untuk meminimasi total waktu produksi, untuk itu maka nilai fitness dihitung berdasarkan total completion time. Untuk individu dengan completion time terkecil akan dijadikan sebagai solusi akhir dari proses penjadwalan mesin.

Untuk menghitung nilai completion time digunakan rumus:

$$
C_{i}=F_{i}+r_{i} \text {. }
$$

Fungsi tujuan dari permasalahan penjadwalan job shop ini adalah minimasi completion time, maka dari itu tujuan akhir dari algoritma ini akan dicari individu dengan nilai completion time terkecil.

\section{d. Seleksi}

Tahapan selanjutnya adalah proses seleksi, proses ini merupakan tahapan dimana masing-masing individu akan mengalami proses seleksi. Proses ini dilakukan untuk menentukan individu-individu yang akan digunakan sebagai induk untuk proses kawin silang dan mutasi. Proses seleksi pada kasus penjadwalan job shop ini memiliki langkah-langkah sebagai berikut:

- Menghitung nilai fitness tiap individu.

- Menghitung total nilai fitness.

- Menghitung probabilitas fitness masing-masing individu.

$$
\text { prob fitness }(i)=\frac{\text { fitmessi }}{\text { totalfitmess }} \text {. }
$$

- Membangkitkan 2 buah bilangan random untuk memilih individu induk.

- Menentukan individu induk untuk digunakan pada proses kawin silang atau mutasi.

\section{e. Perkawinan Silang}

Perkawinan silang (crossover) merupakan proses selanjutnya dalam Genetic Algorithm. Pada proses ini dua buah individu induk akan melakukan pertukaran gen untuk menghasilkan individu baru yang selanjutnya akan diuji kembali nilai fitness individu tersebut. Dalam proses kawin silang ini sifat-sifat dari induk akan diturunkan kepada individu anak sehingga dapat menghasilkan individu baru yang lebih baik. Proses kawin silang ini bisa dilakukan atau tidak, apabila tidak dilakukan maka sifatsifat dari induk akan diturunkan secara langsung kepada individu anak.

\section{f. Mutasi}

Tahapan mutasi adalah tahapan proses dalam Genetic Algorithm dimana sejumlah gen akan dimasukan untuk menggantikan gen yang hilang dari individu pada proses sebelumnya. Kromosom anak akan dimasukan sejumlah nilai dengan probabilitas yang sangat kecil. Proses ini dilakukan karena pada proses perkawinan silang dimungkinkan adanya sejumlah gen yang hilang atau individu yang tidak sesuai dengan solusi yang diharapkan, sehingga gen baru akan dimasukan untuk menggantikan gen yang lama sehingga individu baru yang terbentuk sesuai dengan solusi.

\section{g. Pembentukan Individu Baru}

Setelah semua proses dalam Genetic Algorithm tersebut dijalankan, maka akan muncul individu baru yang dibentuk. Individu tersebut merupakan solusi akhir dari permasalahan dalam penjadwalan mesin. Sebelum individu baru ini diaplikasikan menjadi sebuah solusi, dilakukan pengujian terhadap individu baru tersebut. Pengujian dilakukan dengan cara menghitung nilai fitness individu baru. Apabila nilai fitness individu baru sudah berada pada kondisi steady state, maka proses komputasi dapat 
dihentikan dan individu baru tersebut siap untuk diaplikasikan sebagai solusi dari permasalahan penjadwalan mesin. Apabila nilai yang dihasilkan belum optimal, maka kembali ke langkah seleksi dan seterusnya hingga didapatkan nilai yang optimal.

- Tahap 3: Tahapan terakhir dalam penelitian ini adalah membandingkan hasil pengolahan data dengan menggunakan metode Genetic Algorithm dengan hasil perhitungan pada penelitian sebelumnya dengan menggunakan metode Heuristic Dispatching Rules berdasarkan kriteria Cmax (Completion Time Maximum) serta nilai efisiensi penjadawalan mesin.

\section{HASIL DAN ANALISIS}

\section{A. Pengumpulan Data}

CV Boeing Teknik Mandiri merupakan perusahaan manufaktur yang memproduksi part yang membantu dalam proses perakitan dunia otomotif. CV Boeing Teknik Mandiri memiliki 8 aktivitas utama pada lantai produksi. Aktivitas-aktivitas tersebut adalah:

- Bagian Pemotongan (Mesin 1)

- Bagian Pengeboran (Mesin 2)

- Bagian Pembubutan (Mesin 3)

- Bagian Penguliran (Mesin 4)

- Bagian Milling (Mesin 5)

- Bagian Grinding (Mesin 6)

- Bagian Hardening (Mesin 7)

- Bagian Knurling (Mesin 8)

Pada penelitian ini, CV Boeing Teknik Mandiri mengerjakan 20 job pesanan konsumen dengan daftar job sebagai berikut:

Tabel 1 Daftar Job

\begin{tabular}{|c|c|c|c|}
\hline \multicolumn{4}{|c|}{ JOB } \\
\hline No & Nama & Qty & $\begin{array}{l}\text { Due } \\
\text { date }\end{array}$ \\
\hline 100 & BUSHING & 10 & 6 \\
\hline 200 & PILOT PIN SC 037 & 5 & 6 \\
\hline 300 & PILOT PIN SC 038 & 5 & 6 \\
\hline 400 & PILOT PIN SC 039 & 5 & 6 \\
\hline 500 & PILOT PIN SC 040 & 5 & 6 \\
\hline 600 & PILOT PIN SC 041 & 5 & 6 \\
\hline 700 & PILOT PIN SC 042 & 5 & 6 \\
\hline 800 & PILOT PIN SC 043 & 5 & 6 \\
\hline 900 & PILOT PIN SC 083 & 5 & 7 \\
\hline 1000 & PILOT PIN (ROUGH) SC-121 & 8 & 7 \\
\hline 1100 & PILOT PIN (ROUGH) SC-122 & 8 & 7 \\
\hline 1200 & PIN B06-06 & 10 & 7 \\
\hline 1300 & PIN B06-05 & 6 & 7 \\
\hline 1400 & PIN B04-05 & 5 & 6 \\
\hline 1500 & BUS-JBN.8 & 4 & 5 \\
\hline 1600 & PIN GURIS & 4 & 5 \\
\hline 1700 & CARRIER YR9 & 24 & 7 \\
\hline 1800 & HING PIN & 24 & 5 \\
\hline 1900 & HANDLE 02 & 4 & 7 \\
\hline 2000 & HANDLE 03 & 4 & 6 \\
\hline
\end{tabular}

(Sumber: Iskandar, 2013) 
Tabel di atas merupakan daftar job pesanan yang diterima oleh CV Boeing Teknik Mandiri. Dari tabel di atas diketahui bahwa batas penyelesaian waktu pesanan paling cepat yang diminta konsumen adalah 5 hari, dan untuk yang paling lama adalah 7 hari. Berdasarkan tabel daftar pesanan tersebut, maka dibuatlah routing sheet untuk mempermudah pengontrolan terhadap proses produksi (Iskandar, 2013).

Urutan proses operasi dibuat untuk mengetahui urutan suatu job dalam melewati mesin pada lantai produksi. Urutan proses operasi dapat dilihat pada tabel 2 berikut.

Tabel 2 Urutan Proses Operasi

\begin{tabular}{|c|c|c|c|c|c|c|c|}
\hline \multirow{2}{*}{ Job } & \multicolumn{7}{|c|}{ Operasi } \\
\cline { 2 - 8 } & $\mathbf{1}$ & $\mathbf{2}$ & $\mathbf{3}$ & $\mathbf{4}$ & $\mathbf{5}$ & $\mathbf{6}$ & $\mathbf{7}$ \\
\hline 100 & 2 & 1 & 3 & 6 & 7 & & \\
\hline 200 & 1 & 3 & 5 & 4 & 6 & 7 & \\
\hline 300 & 3 & 4 & 1 & 6 & 7 & & \\
\hline 400 & 1 & 4 & 3 & 6 & 7 & & \\
\hline 500 & 1 & 3 & 4 & 6 & 7 & & \\
\hline 600 & 3 & 5 & 1 & 4 & 6 & 7 & \\
\hline 700 & 1 & 3 & 4 & 5 & 6 & 7 & \\
\hline 800 & 3 & 4 & 1 & 6 & 7 & & \\
\hline 900 & 1 & 3 & 4 & 6 & 7 & & \\
\hline 1000 & 3 & 4 & 1 & 6 & 7 & & \\
\hline 1100 & 3 & 5 & 4 & 6 & 1 & 7 & \\
\hline 1200 & 3 & 5 & 4 & 1 & 6 & 7 & \\
\hline 1300 & 3 & 5 & 4 & 1 & 6 & 7 & \\
\hline 1400 & 1 & 3 & 5 & 4 & 6 & 7 & \\
\hline 1500 & 2 & 3 & 1 & 6 & 7 & & \\
\hline 1600 & 1 & 4 & 5 & 3 & 6 & 8 & 7 \\
\hline 1700 & 3 & 5 & 1 & 7 & & & \\
\hline 1800 & 4 & 3 & 5 & 1 & 6 & 7 & \\
\hline 1900 & 3 & 1 & 4 & 6 & 7 & 8 & \\
\hline 2000 & 1 & 3 & 4 & 6 & 7 & 8 & \\
\hline
\end{tabular}

(Sumber: Iskandar, 2013)

Tabel diatas menunjukan urutan mesin yang dilalui sebuah job pada proses produksi. Sebagai contoh job 100 operasi pertama melalui mesin 2, operasi kedua melalui mesin 1 , operasi ketiga melalui mesin 3 , operasi keempat melalui mesin 6 , dan operasi kelima melalui mesin 7.

Tabel 3 berikut menunjukan waktu siklus masing-masing mesin yang ada di lantai produksi CV Boeing Teknik Mandiri. Waktu siklus yang diolah merupakan waktu siklus tiap mesin setiap operasi dikalikan dengan banyaknya jumlah pesanan.

Tabel 3 Waktu Operasi Mesin

\begin{tabular}{|c|c|c|c|c|c|c|c|c|}
\hline \multirow{2}{*}{ JOB } & \multicolumn{7}{|c|}{ WAKTU OPERASI (DETIK) } \\
\cline { 2 - 10 } & M1 & M2 & M3 & M4 & M5 & M6 & M7 & M8 \\
\hline 100 & 3777 & 1264 & 4096 & & & 7465 & 9032 & \\
\hline 200 & 1237 & & 2406 & 2526 & 2756 & 4240 & 4532 & \\
\hline 300 & 1871 & & 1771 & 1282 & & 4500 & 4532 & \\
\hline 400 & 1437 & & 2121 & 1876 & & 4660 & 4532 & \\
\hline 500 & 2372 & & 1981 & 1866 & & 3535 & 4532 & \\
\hline 600 & 1396 & & 1367 & 886 & 2861 & 3265 & 4532 & \\
\hline
\end{tabular}




\begin{tabular}{|c|c|c|c|c|c|c|c|c|}
\hline 700 & 2257 & & 2651 & 1341 & 1751 & 4365 & 4532 & \\
\hline 800 & 727 & & 1861 & 1311 & & 3825 & 4532 & \\
\hline 900 & 1797 & & 2591 & 1651 & & 4725 & 4532 & \\
\hline 1000 & 1235 & & 1736 & 3487 & & 5663 & 7232 & \\
\hline 1100 & 1083 & & 4224 & 2455 & 2122 & 7863 & 7232 & \\
\hline 1200 & 3227 & & 2876 & 2541 & 1536 & 9335 & 9032 & \\
\hline 1300 & 2049 & & 2218 & 1627 & 1028 & 5019 & 5432 & \\
\hline 1400 & 1375 & & 1926 & 1471 & 1651 & 1367 & 4532 & \\
\hline 1500 & 1155 & 736 & 1128 & & & 1439 & 3632 & \\
\hline 1600 & 995 & & 1288 & 1147 & 1150 & 1319 & 3632 & 607 \\
\hline 1700 & 13059 & & 9640 & & 43226 & & 21632 & \\
\hline 1800 & 11139 & & 5776 & 4351 & 2906 & 21759 & 21632 & \\
\hline 1900 & 887 & & 1288 & 1163 & & 1407 & 3632 & 551 \\
\hline 2000 & 1419 & & 1060 & 1491 & & 1067 & 3632 & 599 \\
\hline
\end{tabular}

(Sumber: Iskandar, 2013)

Tabel diatas menunjukan waktu yang dibutuhkan sebuah job dalam melewati sebuah mesin sesuai dengan jumlah pesanan. Sebagai contoh job 100 dengan jumlah pesanan sebanyak 10 melewati mesin 1 selama 3777 detik, melewati mesin 3 selama 1264 detik, melewati mesin 3 selama 4096 detik, melewati mesin 6 selama 7465 detik, dan melewati mesin 7 selama 9032 detik.

Beberapa parameter yang digunakan dalam metode Genetic Algorithm pada penelitian ini adalah populasi awal sebanyak 200 individu, probabilitas crossover sebesar 0,95 dan probabilitas mutasi sebesar 0,05. Parameter yang digunakan dalam metode Genetic Algorithm ditunjukan pada gambar 2 berikut.

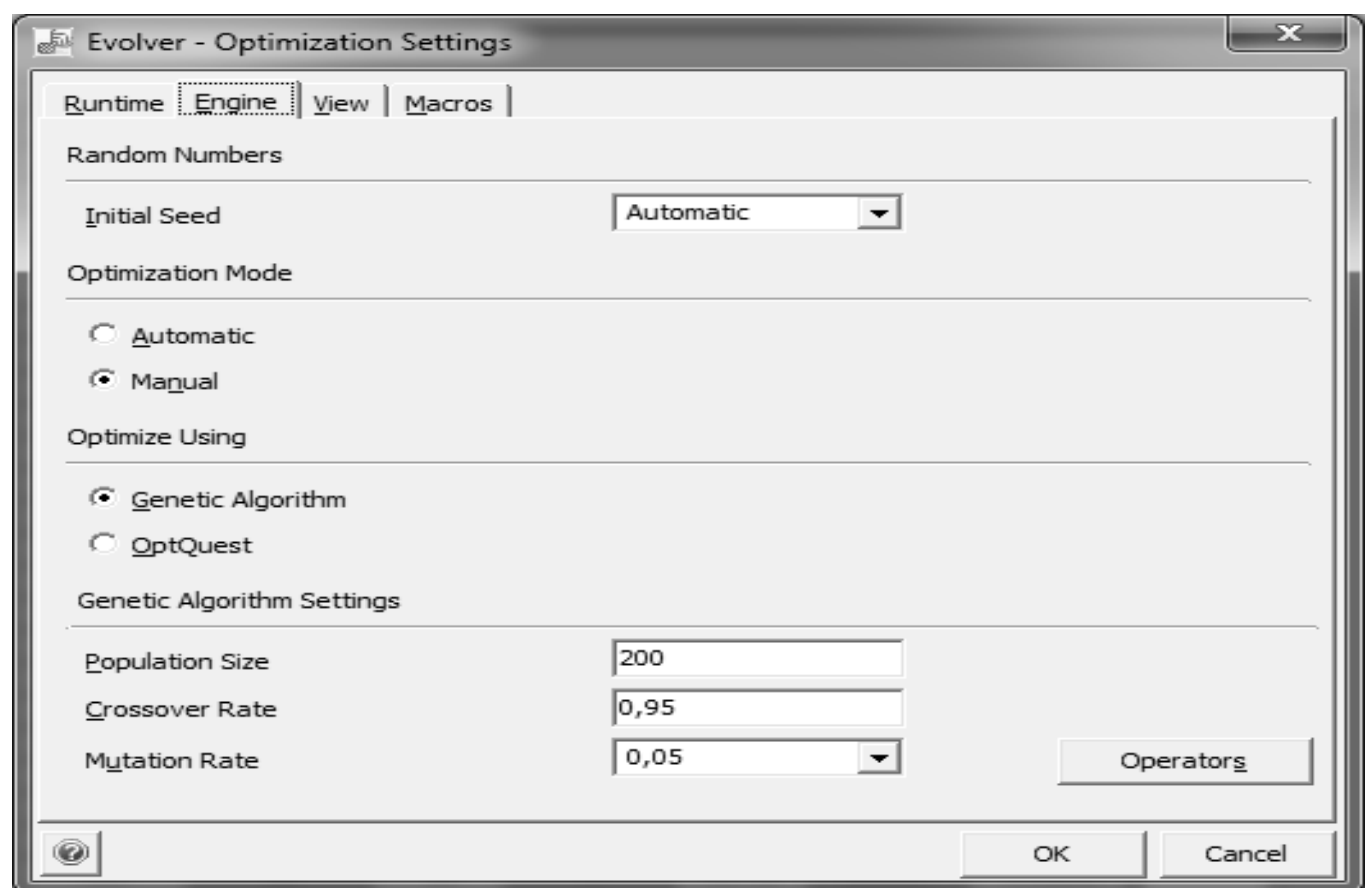

\section{Gambar 2 Parameter Genetic Algorithm}

Jumlah iterasi yang dilakukan dalam penjadwalan dengan metode Genetic Algorithm adalah sebanyak 130303 iterasi dengan total waktu komputasi selama 27 menit 33 detik. Iterasi dihentikan karena nilai fitness dari kasus sudah berada pada kondisi steady state yang ditunjukan pada gambar 3 berikut. 


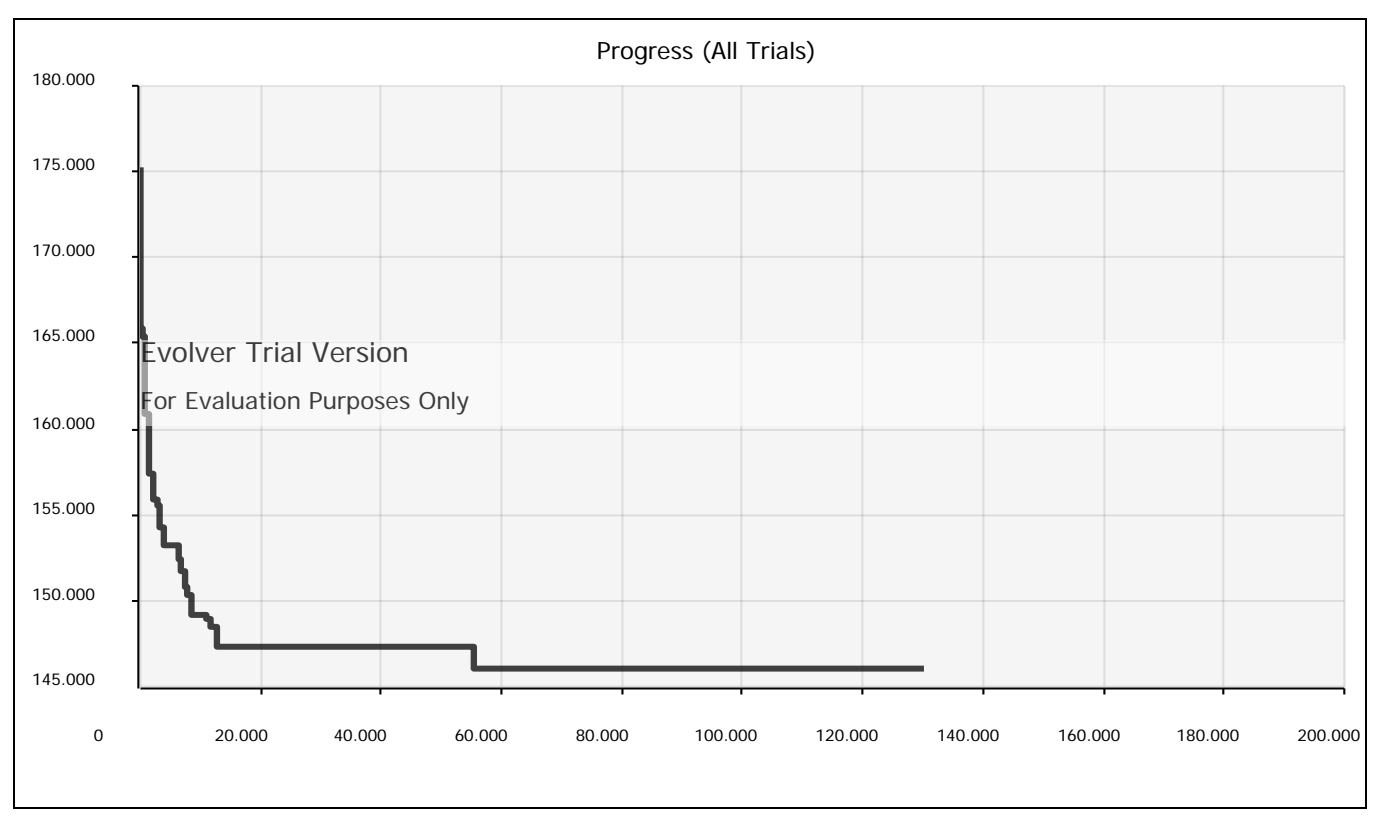

Gambar 3 Progress Genetic Algorithm

\section{B. ANALISIS HASIL KRITERIA}

Hasil kriteria yang diperoleh untuk penjadwalan mesin CV Boeing Teknik Mandiri dengan menggunakan metode Genetic Algorithm dan metode Heuristic Dispatching Rules dapat dilihat pada tabel 4 dan 5 berikut:

Tabel 4 Ringkasan Kriteria Penjadwalan dengan Metode Genetic Algorithm

\begin{tabular}{|c|c|c|c|c|}
\hline Prioritas & Detik & Menit & Jam & Hari \\
\hline Cmax : & 143461 & 2391,017 & 39,85 & 4,98 \\
\hline Fmax : & 143461 & 2391,017 & 39,85 & 4,98 \\
\hline Lmax : & -9063 & $-151,05$ & $-2,51$ & 0,31 \\
\hline Tmax : & 0 & 0 & 0 & 0,00 \\
\hline
\end{tabular}

(Sumber: Data Diolah)

Tabel 5 Ringkasan Kriteria Penjadwalan Metode Heuristic Dispatching Rules

\begin{tabular}{|c|c|c|c|c|}
\hline \multirow{2}{*}{ Prioritas } & \multicolumn{4}{|c|}{ Kriteria Kinerja } \\
\cline { 2 - 5 } & $\begin{array}{c}\text { Cmax } \\
\text { (menit) }\end{array}$ & $\begin{array}{c}\text { Lmax } \\
\text { (menit) }\end{array}$ & $\begin{array}{c}\text { Fmax } \\
\text { (menit) }\end{array}$ & $\begin{array}{c}\text { Tmax } \\
\text { (menit) }\end{array}$ \\
\hline LWKR & 2442,27 & 2442,15 & 2442,27 & 2442,15 \\
\hline EDD & 2523,58 & 2523,47 & 2523,58 & 2523,47 \\
\hline
\end{tabular}

(Sumber: Iskandar, 2013)

\section{- $\quad$ Cmax (Completion Time)}

Cmax (Completion Time) adalah lama waktu penyelesaian pekerjaan maksimum yang dimulai dari pengerjaan tugas pertama. Berdasarkan kriteria Cmax (completion time) pada tabel 5.1 bahwa dengan menggunakan metode Genetic Algorithm dihasilkan nilai sebesar 2391,017 menit, yang artinya bahwa lama proses produksi maksimum dilakukan selama 2391,017 menit kerja. Sementara dengan menggunakan metode Heuristic Dispatching Rules dengan kriteria terpilih yaitu Least Work Remaining ( $L W K R$ ) didapatkan nilai Cmax sebesar 2442,27 menit, yang artinya proses produksi dilakukan selama 2442,27 menit kerja. Untuk proses penjadwalan awal CV Boeing Teknik Mandiri dengan menggunakan prioritas Earlies Due Dates (EDD) didapatkan nilai Cmax sebesar 2523,58 menit, yang artinya proses produksi berlangsung 
selama 2523,58 menit kerja. Dari ketiga metode yang digunakan untuk penjadwalan pada CV Boeing Teknik Mandiri dapat dikatakan bahwa dengan metode Genetic Algorithm menghasilkan nilai Cmax yang lebih baik apabila dibandingkan dengan menggunakan metode Heuristic Dispatching Rules. Hal tersebut dikarenakan bahwa dengan menggunakan metode Genetic Algorithm akan menghasilkan nilai Cmax yang lebih kecil dibandingkan metode lainnya.

Kriteria Cmax untuk penjadwalan mesin dengan metode Genetic Algorithm menghasikan efisiensi sebesar 5,25\% bila dibandingkan dengan proses penjadwalan awal dengan prioritas $E D D$, dan $2,1 \%$ bila dibandingkan dengan proses penjadwalan metode Heuristic Dispatching Rules dengan prioritas LWKR yang dilakukan oleh Iskandar (2013).

$$
\begin{aligned}
& \text { - } \frac{2391_{8} 017-2523,58}{2523,58} \times 100 \%=5,25 \% \\
& \text { - } \frac{2391_{0}, 017-2442,27}{2442,27} \times 100 \%=2,1 \%
\end{aligned}
$$

\section{KESIMPULAN}

Kesimpulan yang dapat diambil dari hasil penelitian dari penjadwalan mesin yang telah dilakukan diantaranya adalah:

1. Penjadwalan mesin untuk CV Boeing Teknik Mandiri dengan menggunakan metode Genetic Algorithm menghasilkan nilai kriteria Cmax sebesar 2391,017 menit, nilai kriteria Fmax sebesar 2391,017 menit, nilai kriteria Lmax sebesar -151,05 menit, dan nilai kriteria Tmax sebesar 0 menit.

2. Hasil penjadwalan mesin dengan menggunakan metode Genetic Algorithm untuk CV Boeing Teknik Mandiri dengan kriteria completion time menghasilkan penjadwalan yang lebih baik dibandingkan dengan penelitian sebelumnya dengan menggunakan metode Heuristic Dispatching Rules dengan efisiensi penjadwalan sebesar 5,25\% dibandingkan dengan penjadwalan awal, dan 2,1\% bila dibandingkan dengan penelitian sebelumnya dengan metode Heuristic Dispatching Rules.

\section{DAFTAR PUSTAKA}

[1] Adhy, S. dan Kushartantya, Penyelesaian Masalah Job Shop Menggunakan Algoritma Genetika, Jurnal Masyarakat Informatika, Volume 1, Nomor 1.

[2] Baker, K.R., 2009, Princeiple Introduction to Sequencing and Scheduling. John Willey \& Sons, New York.

[3] Chen, K.C. Ian H., dan Cao A. W., 2003, A Genetic Algorithm for Minimum Tetrahedralization of a Convex Polyhedron, CCCG 2003, Halifax, Nova Scotia.

[4] Entin, 2010, Kecerdasan Buatan (Bab 7 Algoritma Genetika), Politeknik Elektronika Negeri Surabaya, Surabaya.

[5] Iskandar, C. Dea, 2013, Implementasi Penjadwalan Mesin Job Shop Dengan Metode Heuristic Dispatching Rules di CV Boeing Teknik Mandiri, Skripsi, Program Studi Teknik Industri , Universitas Widyatama, Bandung.

[6] Nahmias, S., 1997, Production and Operation Analysis, McGraw-Hill, New York.

[7] Narasimhan, S. L., 1995, Production Planning and Inventory Control, Prentice-Hall, New Jersey.

[8] Omar, M., Baharum, and Y. Abu Hasan, 2006, "A Job Shop Scheduling Problem (JSSP) Using Genethic Algorithm (GA)”, Proceedings of $2^{\text {nd }}$ IMT-GT Regional Conference on Mathematics, Statistics and Aplications, Universiti Sains Malaysia, Penang.

[9] Satrio, A. Bayu, 2007, Optimasi Masalah Penjadwalan Job Shop Untuk Industri Peralatan Pengolahan Hasil Pertanian Dengan Menggunakan Algoritma Genetika, Skripsi, Fakultas Teknologi Pertanian, Institut Pertanian Bogor, Bogor. 
[10] Syarif, A. dan Mitsuo G, 2003, Hybridized Parallel Genetic Algorithm for Facility Location Problem, Makalah Penelitian IlmuKomputer.com.

[11] http://www.palisade.com/trials.asp, diakses tanggal 3 Mei 2013, 00:41 WIB. 